children, purposefully enriching their artistic experience, fostering music appreciation in them, selecting the appropriate repertoire, establishing positive relations with families, etc. There have been considered methods of pop vocal lessons including usage of rhythm and movement exercises, oriented at the development of emotionality and muscle tension release, involving children into pop forms of music-making, where the positive style of communication, moral qualities, kindness, ability to empathize are formed. The peculiarities of the methods of pop vocal teaching involve searching for one's individual style without imitating adult artists, using a number of tasks aiming to improve artistry and culture of stage behavior of primary school students, creating dialogue and communicative, music and creative situations in pop vocal forms of music-making. The following criteria of repertoire selection have been distinguished: correspondence to primary school students' age characteristics of perceiving, artistic value of music and poetry; diversity of emotional states, etc. The possibility of role interpretation of child repertoire, implementing movement and stage elements of artistry (mimics, gestures) are considered to be important characteristics of child repertoire. The prospects of the further research involve the development of methods of encouraging primary school students towards pop singing, which relieves stresses in the process of preparing for public performance, saves and develops the natural character and sincerity in their performance activities.

Keywords: junior school students, pop singing, personal development, pedagogical conditions.

Подано до редакиіï 13.01.2016

Рецензент: д. пед. н., проф. О. С. Реброва

УДК: $378+378.147+371.826 .91$

Viktoriia Sakharova,

lecturer, Department of Germanic Philology and Methods of Foreign Languages Teaching, South Ukrainian National Pedagogical University named after K. D. Ushynsky, 34, Staroportofrankivska Str., Odesa, Ukraine

\title{
IMPLEMENTATION OF PEDAGOGICAL CONDITIONS OF FOREIGN STUDENTS' PROFESSIONAL AND PEDAGOGICAL CULTURE FORMATION IN THE PROCESS OF PROFESSIONAL TRAINING
}

The article deals with the stages, content of research and experimental work on the implementation of pedagogical conditions of foreign students' professional and pedagogical culture formation in the process of professional training (attracting foreign students to the creation of a multicultural environment; orientation of the educational process at developing abilities and interpersonal skills of communication; organization of foreign students' creative activities by means of interactive teaching methods). There have been presented stages of constructing the model of foreign students' professional and pedagogical culture formation in the process of professional training which included a phased (directive, practical, creative stages) implementation with introduction of pedagogical conditions and complex influence on the formation of the examined foreign students' professional and pedagogical culture constituents. The structure of a developed special course aimed at the foreign students' professional-pedagogical culture formation in the process of professional training is revealed. It has been concluded that the introduction of pedagogical conditions contributes to increasing of the efficiency of foreign students' professional and pedagogical culture formation in the process of professional training.

Keywords: pedagogical conditions, professional and pedagogical culture of foreign students, interactive teaching methods.

Problem statement. New trends in education that emerged at the turn of the second and third millennia, new paradigms of education, a new system of educational social values and goals, its dialogue with the culture of a man as its creator and subject, capable of cultural self-education stimulated particular interest in the phenomenon of "foreign students' professional and pedagogical culture".

Review of recent publications. Particular interest to the initiated research is in the works of the authors who explore the theoretical framework, the essence, the structure, and the process of professional and pedagogical culture formation: O. Barabanschykov, E. Bondarevskaya, M. Bukach, A. Garmash, V. Grinyov, T. Ivanova, I. Isaev,
L. Necheporenko,
V. Radul,
A. Rudnytska,

V. Sukhomlinsky and others.

Thus, E. Bondarevska considers professional and pedagogical culture as a part of human culture, which reveals its content in global teaching experience as a change of cultural eras and relevant teaching civilizations, as history of teaching science and practice, as a change of educational paradigms [1]. T. Ivanova has the similar thought; she believes that professional and pedagogical culture is the integral quality of teacher's personality, projecting its common culture within the scope of the profession; a synthesis of professionalism and the intrinsic teacher properties, mastering teaching methods and the availability of cultural skills [2]. 
However, the problem of foreign students' professional and pedagogical culture formation in the process of professional training has not been the subject of special studies and has not been reflected in scientific works of scholars.

The purpose of the article is to describe the process of implementation of pedagogical conditions of foreign students' professional and pedagogical culture formation in the process of professional training.

Major content. There are different approaches to the definition of the essence of "pedagogical conditions" in Pedagogy. A. Nazarova considers pedagogical conditions as a set of objective capabilities, content, forms, methods, teaching methods and material and spatial environment aimed at solving research problems [3]. A. Postalyuk believes that pedagogical conditions are teaching conditions that promote (or oppose) the manifestation of pedagogical patterns due to the influence of certain factors [4].

In the context of research pedagogical conditions are defined as specially created circumstances that promote foreign students' professional and pedagogical culture formation in the process of their professional training. We have identified the following pedagogical conditions: attracting foreign students to the creation of a multicultural environment; orientation of the educational process in developing abilities and interpersonal skills of communication; organization of foreign students' creative activities by means of interactive teaching methods.

In the course of the research the model of implementation of the determined pedagogical conditions that allows to visualize the educational process aimed at achieving the intended result - foreign students' professional and pedagogical culture formation in the process of professional training - has been developed.

The model includes the phased (directive, practical, creative) implementation of pedagogical conditions and is aimed at creating foreign students' professional and pedagogical culture formation, its structure includes ethnic, personal, behavioral constituents that are measured by culturological (indicators: knowledge of ethnic and religious backgrounds, availability of social and individual values, communicative tolerance), intellectual and creative (indicators: empathy, emotional intelligence, creativity) and active (performance, availability of motivation to succeed in the profession, interaction style, reflective skills) criteria. The result of the model implementation is foreign students' professional and pedagogical culture formation.

The directive stage involves the knowledge acquisition by the students about the essence of professional and pedagogical culture. These pedagogical conditions are implemented by means of lectures (traditional and interactive), discussions, practicals, seminars and debates, and also such kinds of independent work, as work with informative sources (drafting summaries, writing essays, reports, thesaurus of pedagogical terms preparation).

The practical stage is aimed at the acquisition of practical skills of foreign students that are the parts of the professional and pedagogical culture, working them through the use of role-playing games, solving educational situations, conflict resolution, various kinds of extracurricular work, independent creative activity.

The creative stage involved the use of students' acquired knowledge and skills in the performance of individual creative tasks, brain-ring, making projects, presentations, essays, debates, etc.

108 foreign third-year-students participated in the forming part of the experiment, there has been held a specially organized experimental work. They formed the experimental group. The purpose of the forming stage of the experiment was to test the effectiveness of the model realization and methods of denoted pedagogical conditions implementation in the experimental group. In the control group (112 people) studying was carried out according to the traditional programme, without the implementation of pedagogical conditions of foreign students' professional and pedagogical culture formation.

The primary means of implementing pedagogical conditions in the educational process at the directive stage is the introduction of the developed 28-hour course "Fundamentals of professional and pedagogical culture formation of foreign students-future teachers" 6 hours of which are given for the lectures, 10 hours - for practical courses, 6 hours - for students' independent work and 6 hours for the performance of individual creative tasks.

The purpose of the special course is the foreign students' professional and pedagogical culture formation in the process of professional training.

The task of the special course is to familiarize the students with the definition of the essence of "professional and pedagogical culture", the formation of knowledge about religious and cultural characteristics of different ethnic, social and personal values, communication and tolerance skills, and abilities to control their emotions and understand the emotional state of others, analyze their and students' actions, solve various pedagogical problems and conflicts, quickly make optimal decisions in situations arising, etc.

At the end of the special course students must master the abilities and skills of professional and pedagogical culture, learn how to control their emotions, tolerate students and colleagues of different faiths and ethnicity, find an individual approach to each student to be able to prevent conflict situations, communicate and collaborate with teaching staff, children and their parents, etc.

The learning process at the directive stage is different by means of its cumulative nature. The teaching forms are interactive lectures ("Professional and pedagogical culture: its essence and components"; "Ethnicity and religion as the basis of knowledge of other cultures"; "Tolerance and its role in creating multicultural environment") during which students not only received new theoretical knowledge, but also had the opportunity to ask questions, express their opinion, give their own definitions of the key concepts of the lecture. This form of lectures helped students acquire the necessary theoretical knowledge and motivation to improve learning and teaching activities in general. 


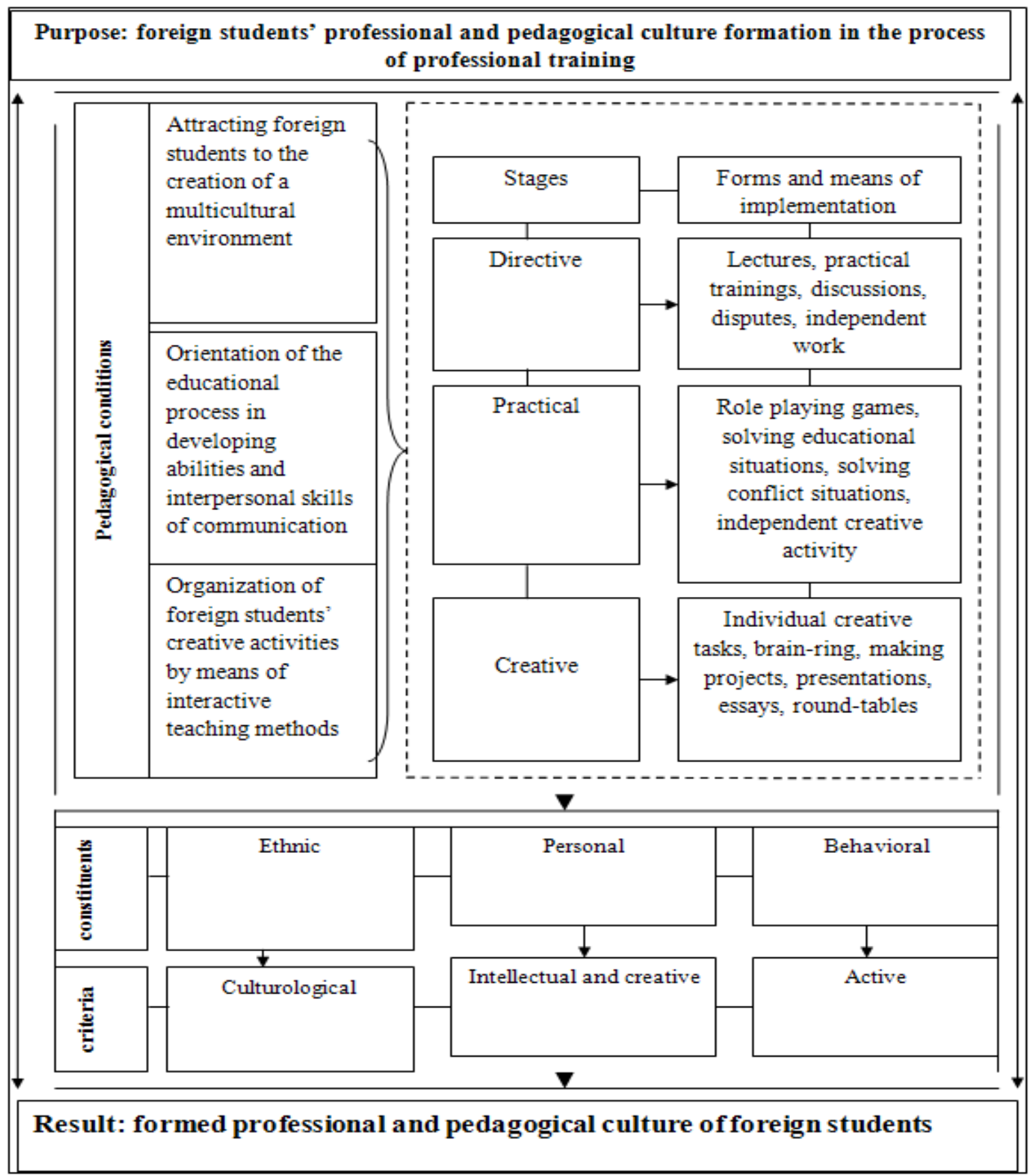

Pic. 1. Model of future teachers' professional and pedagogical culture formation in the process of professional training

After the course at the directive stage foreign students came to the conclusion that a competent teacher should be systematic, have fundamental knowledge not only of his/her subject and be well informed about the features of different ethnic groups and religions, keep close to them in the educational process to create a multicultural environment. A teacher should enable students to develop their skills, and instill love and interest in different ethnic groups in them, teach them how to conduct a competent dialogue of cultures, which in turn will have positive impact the learning process in general. The students have concluded that teacher's professional and pe- dagogical culture involves constant learning, selfimprovement, being interesting for children.

Upon completion of practical trainings - at the creative stage - foreign students were invited to the "Festival of the Nations", during which future teachers demonstrated their national costumes, dances, songs, talked about the importance of their colours, symbols and anthem, peculiarities of national cuisine.

During the practical trainings - at practical stage students were proposed a business game "Tolerance in conflict situations', the solution of educational problems ("Clown in class", "There is a new girl in the class with a deeply religious Muslim family. The girl holds religious 
and ethnic customs. Some children do not understand it and laugh over it. What should you do?"; "There is a boy from another country who welcomes teachers in his native language and according to the custom of his country. Children teased him for it. What should you do?"), holding debates ("Can a teacher lose patience?"), etc.

Since the fact that only 28 hours are given for the special course the issue of foreign students' professional and pedagogical culture formation was considered during the academic disciplines such as "Pedagogy", "English", "Psychology", "Culture Studies". The teachers who agreed to participate in the experimental work took part in a seminar during which they were presented the purpose and objectives of the experiment.

Thus, when teaching "Pedagogy" the attention of foreign students was paid to the acquisition of tolerance as the ability to understand and forgive the shortcomings of other people, the ability to perceive them as they are, which is one of the main requirements for a teacher, the ability to strengthen interpersonal relationships and improve the microclimate in a multicultural class. During the Psychology classes one of the objectives was to teach foreign students how to diagnose their own and their potential students' emotional state, gain skills to diagnose emotions, exercise patience. The aim of the classes " $\mathrm{Cul}$ -

\section{ЛІТЕРАТУРА}

1. Бондаревская, Е. В. Педагогическая культура как общественная и личная ценность / Е.В.Бондаревская // Педагогика. - 1999. - № 3. - С. 37-43.

2. Іванова Т. В. Професійна культура майбутнього вчителя / Т. В. Іванова // Педагогіка і психологія. 1995. - № 2. - C. 86-93.

3.Назарова О. Л. Новые информационные техно-

\section{REFERENCES}

1.Bondarevskaya, E. V. (1999). Pedagogicheskaya kultura kak obschestvennaya i lichnaya tsennost [Pedagogical culture as public and personal value]. Pedagogika - Pedagogy, 3, 37-43 [in Russian].

2.Ivanova, T. V. (1995). Profesiina kultura maibutniogo vchytelya [Future teacher's professional culture]. Pedagogika i psykhologiya - Pedagogy and psychology, 2, 86-93 [in Ukrainian]. ture Studies" was to teach students to be tolerant to other people. Awareness of their religious and cultural peculiarities will prevent the emergence of conflicts on religious grounds.

The implementation of pedagogical conditions has contributed to increasing the efficiency of future students' professional and pedagogical culture formation in the process of their professional training, which confirmed the results of the final phase of the research. Thus, the formation of a high level of professional and pedagogical culture reached $30,8 \%$ of EG students (was 15,7\%) and $23,2 \%$ CG (was 17,1\%), satisfactory level $53,3 \%$ of respondents $(46,6$ was $\%$ ), on the low level remained $15,9 \%$ of future teachers (was $37,6 \%$ ).

Conclusions. The implementation of pedagogical conditions contributed to increasing the efficiency of future students' professional and pedagogical culture formation in the process of professional training, which confirmed the results of the final phase of the research. The results obtained in the experimental work indicate the appropriateness of the model realization of foreign students' professional and pedagogical culture formation with the implementation of the denoted pedagogical conditions at a higher educational institution.

логии в управлении качеством образовательного процесса в колледже / О. Л. Назарова // Информатика и образование. - 2003. - № 11. - С. 79-84.

4.Посталюк Н. Ю. Творческий стиль деятельности: педагогический аспект / Н. Ю. Посталюк - Казань: Казанский ун-т, 1989. - 205 с.

3. Nazarova, O. L. (2003). Novyie informatsionnyie tehnologii $\mathrm{v}$ upravlenii kachestvom obrazovatelnogo protsessa $\mathrm{v}$ kolledzhe [New information technologies in management of educational process quality in college]. Informatika i obrazovanie - Computer sciences and education, 11, 79-84 [in Russian].

4.Postalyuk, N. Yu. (1989). Tvorcheskiy stil deyatelnosti: pedagogicheskiy aspekt [Creative style of activity: pedagogical aspect]. Kazan: Kazanskiy un-t [in Russian].

\section{Вікторія Вікторівна Сахарова, викладач кафедри германської філології та методики навчання іноземних мов, Південноукраїнський національний педагогічний університет імені К. Д. Уиинського, вул. Старопортофранківська, 34, м. Одеса, Украӥна}

\section{РЕАЛІЗАЦІЯ ПЕДАГОГІЧНИХ УМОВ ФОРМУВАННЯ ПРОФЕСІЙНО-ПЕДАГОГІЧНОӤ КУЛЬТУРИ ІНОЗЕМНИХ СТУДЕТІВ У ПРОЦЕСІ ФАХОВОЇ ПІДГОТОВКИ}

У статті висвітлено етапи та зміст дослідно-експериментальної роботи з реалізації педагогічних умов формування професійно-педагогічної культури іноземних студентів у процесі фахової підготовки (залучення іноземних студентів до створення полікультурного середовища; орієнтування навчального процесу на формування вмінь і навичок міжособистісного спілкування; організація творчої діяльності іноземних студентів засобами інтерактивних методів навчання). Зазначено етапи побудови моделі формування професійно-педагогічної куль- 
тури іноземних студентів у процесі фахової підготовки, що передбачала поетапну (ознайомлювальний, практичний, творчий етапи) реалізацію з упровадженням визначених педагогічних умов і комплексно впливала на формування виокремлених складових формування професійно-педагогічної культури іноземних студентів. Визначено форми і засоби реалізації педагогічних умов на кожному етапі (ознайомлювальний - лекції (традиційні та інтерактивні), лекції-дискусії, практичні заняття, семінари та диспути, а також використання таких видів самостійної роботи студентів, як робота з інформативними джерелами (складання конспектів, написання рефератів, доповідей, складання тезаурусу педагогічних термінів); практичний - упровадження рольових ігор, вирішення педагогічних ситуацій, розв'язання конфліктів, проведення різних позааудиторних видів роботи, самостійної творчої діяльності; творчий - виконання індивідуальних творчих завдань, проведення брейн-рингів, захисту проектів, презентацій, рефератів, круглих столів). Розкрито структуру розробленого спецкурсу, спрямованого на формування професійно-педагогічної культури іноземних студентів у процесі фахової підготовки. Дійшли висновку, що упровадження визначених педагогічних умов сприяло підвищенню ефективності процесу формування професійно-педагогічної культури іноземних студентів у процесі фахової підготовки.

Ключові слова: педагогічні умови, професійно-педагогічна культура іноземних студентів, інтерактивні методи навчання.

Виктория Викторовна Сахарова, преподаватель кафедры германской филологии и методики преподавания иностранных языков, Южноукраинский национальный педагогический университет имени К. Д. Ушинского, ул. Старопортофранковская, 34, г. Одесса, Украина

\section{РЕАЛИЗАЦИЯ ПЕДАГОГИЧЕСКИХ УСЛОВИЙ ФОРМИРОВАНИЯ ПРОФЕССИОНАЛЬНО-ПЕДАГОГИЧЕСКОЙ КУЛЬТУРЫ ИНОСТРАННЫХ СТУДЕНТОВ В ПРОЦЕССЕ ПРОФЕССИОНАЛЬНОЙ ПОДГОТОВКИ}

В статье рассматриваются этапы и суть исследовательской работы по реализации педагогических условий формирования профессионально-педагогической культуры иностранных студентов в процессе профессиональной подготовки (приобщение иностранных студентов к формированию поликультурной среды; ориентация учебного процесса на формирование умений и навыков межличностного общения; организация творческой деятельности иностранных студентов с использованием интерактивных методов обучения). Указаны этапы построения модели формирования профессионально-педагогической культуры иностранных студентов в процессе профессиональной подготовки, которая предусматривала поэтапное (ознакомительный, практический, творческий этапы) внедрение с помощью реализации выделенных педагогических условий и комплексно влияла на формирование выделенных составляющих формирования профессиональнопедагогической культуры иностранных студентов. Определены формы и средства реализации педагогических условий на каждом этапе (ознакомительный этап - лекции (традиционные и интерактивные), лекциидискуссии, практические занятия, семинары и диспуты, а также использование таких видов самостоятельной работы, как работа с информационными источниками (составление конспектов, написание рефератов, докладов, составление тезауруса педагогических терминов); практический - внедрение ролевых игр, решение педагогических задач, разрешение конфликтных ситуаций, проведение различных внеаудиторных видов работы, самостоятельная творческая деятельность; творческий - выполнение индивидуальных творческих заданий, проведение брейн-рингов, защита проектов, презентаций, рефератов, круглых столов). Раскрыта структура разработанного спецкурса, который направлен на формирование профессионально-педагогической культуры иностранных студентов в процессе профессиональной подготовки. Был сделан вывод, что внедрение выделенных педагогических условий способствовало повышению эффективности процесса формирования профессионально-педагогической культуры иностранных студентов в процессе профессиональной подготовки.

Ключевые слова: педагогические условия, профессионально-профессиональная культура иностранных студентов, интерактивные методы обучения.

Рещензент: д. пед. н., проф. Г. Х. Яворська

Подано до редакиіiі 14.01.2016 